\title{
Factors Influencing Second Language Learning Among Urban European Language Learners: A Qualitative Study
}

\author{
B. Poornima ${ }^{*}$, Harini Jayaraman ${ }^{2}$, Dr. Arun Kumar. $A^{3}$
}

\section{ABSTRACT}

Second-language acquisition, second-language learning, or L2 acquisition, is the process by which people learn a second language. The field of second-language acquisition is a sub discipline of applied linguistics, but also receives research attention from a variety of other disciplines, such as psychology and education. We aimed to understand the various factors influencing the second language learning among urban foreign language learners. Between February 2015 and September 2015, we conducted 10 in-depth interviews with a purposive sample of students learning European languages and five key informant interviews with European language teachers in Chennai. Audio recorded interviews were analysed thematically using NVivo 10. The mean age of the participants is 24.7 years. Most of the participants reported professional reasons to learn the language, uninteresting classrooms as a major reason for attrition and previous language learning experience affects their current learning. The need to integrate life and language skills in classes and activities to promote creativity was emphasized by most of them. About half of them said that there is a need to customize courses and use technology like smart boards for making classes more interactive. This paper discusses the findings of the study and its implications in second-language acquisition.

Keywords: Second Language, Motivation, Language acquisition, Chennai

Second language acquisition, or sequential language acquisition, is learning a second language after a first language is already established. There is a difference between Primary Language Acquisition and Secondary Language Acquisition. Stable acquisition of the language structure characterizes primary language acquisition (Brown, 1973; Dulay and Burt, 1975) compared to the correction of errors and learning explicit rules in second language acquisition (Krashen and Seliger, 1975). Second-language acquisition (often abbreviated to SLA) is the scientific discipline devoted to studying that process. The field of second-language acquisition is a sub

\footnotetext{
${ }^{1}$ Co-Researcher, LAMED (Language Acquisition), Chennai

${ }^{2}$ Co-Researcher, LAMED (Language Acquisition), Chennai

${ }^{3}$ Chief Ideator, LAMED, Chennai

*Responding Author

(C) 2016 I B Poornima, H Jayaraman, A Kumar; licensee IJIP. This is an Open Access Research distributed under the terms of the Creative Commons Attribution License (http://creativecommons.org/licenses/by/2.0), which permits unrestricted use, distribution, and reproduction in any Medium, provided the original work is properly cited.
} 


\section{Factors Influencing Second Language Learning Among Urban European Language Learners: A Qualitative Study}

discipline of applied linguistics, but also receives research attention from a variety of other disciplines, such as psychology and education. There are various theories and hypotheses in the field of second-language acquisition about how people learn a second language. Research in second-language acquisition is closely related to several disciplines including linguistics, sociolinguistics, psychology, neuroscience, and education, and consequently most theories of second-language acquisition can be identified as having roots in one of them. Each of these theories can be thought of as shedding light on one part of the language learning process; however, no one overarching theory of second-language acquisition has yet been widely accepted by researchers.

Motivation in second and foreign language learning is a collective cognitive processes from the initiation to the maintenance of second language learning (Pintrich \& Schunk, 2002). The outcomes of language learning can be independent of language learning aptitude if adequate motivation is given (Gardner,1972). According to the self-determination theory of motivation, motivation is naturally and intrinsically present in an individual. Yet another theory of motivation says motivation is built due to extrinsic factors surrounding the individual. Expectancy-value theories state that motivation to learn a language is directly proportional to the individual's expectancy of success in learning the language and the value attached to the process of learning (Dörnyei, 1994). The expectancy of success depends on past experiences, perceived self-efficacy and self-worth. The value attached to the task of learning second language is described in four components: importance attached to the language learning, perceived intrinsic value, extrinsic utility value and the cost of learning the language (Eccles and Wigfield, 1995).

Previous studies have shown that the highly motivated learners are the ones who are successful in learning a language (Jafari, 2013). A study of Hungarian EFL learners revealed a tripartite motivation construct namely; integrativeness, linguistic self-confidence, and the appraisal of the classroom environment (Clément et al, 1994). According to the linguistic self-confidence concept of Richard Clément, self-confidence plays a significant role in foreign language learning. Autonomous style of learning significantly contributes to motivation and the learner attributes success or failure to their own efforts and strategies than external factors, posits the self-determination theory. Also, democratic style of teaching promotes intrinsic motivation (Dickinson, 1995:173-4). The recent studies concentrate on neurobiological models of language acquisition through sustained deep learning based on stimulus appraisal process (Schumann, 1998).

This research focuses on students' perspectives on this subject matter as previous researches have concentrated only on professors' and researchers' perspectives. Since, in the process of learning a language, the role of the student is very significant, it is important to study the factors that motivate them to acquire a new language. A qualitative research method is undertaken to 
explore the various factors that influence second language learning among the urban European language learners.

\section{METHODOLOGY:}

Between February 2015 and September 2015, we conducted 10 in-depth interviews with a purposive sample of students learning European languages and five key informant interviews with European language teachers in Chennai. Ten participants (students and professionals) learning a European Language were selected for the In-depth interviews and professors, head of the departments, directors of language centers and foreign language tutors were selected for key informant interviews. Audio recorded interviews were analysed thematically using NVivo 10. They were initially explored using focused coding and constant comparative method (Charmaz, 2006; Glaser \& Strauss, 1967). Few emergent codes and categories were identified from the text and added to the existing codes of the a priori codes. Axial coding was done to develop connections between categories derived from all data. Themes were identified by looking for similarities, differences and relationships between categories (Gibson \& Brown, 2009).

\section{RESULTS}

\section{Characteristics of the participants:}

The mean age of the participants is 24.8 years. There were eight females and two males. Three of them knew more than one European language. Four of them were students from a city college, one of them a language teacher, three of them were language specialists working in a private company, a home maker and a software engineer made up the rest of the sample. All of them were learning their respective European language level 3 and above according to the CEFR pattern (Common European Framework for the Reference of Languages). Nine of them learnt French as their first foreign language. All of them were actively learning French for at least one year retrospectively from the time of study. Key informants were; Director of International French Institute, Chennai, Head of the Department of Foreign Languages Department in a University, Chennai, and A Spanish tutor, A Professor and Assistant Professor of Foreign Languages Department of a city college.

\section{FINDINGS:}

\section{Reasons to learn a foreign language:}

It was observed that five out of ten participants said that the reason for them to start learning a European Language is for professional benefits. Learning a European Language gave them an edge over the others and also helped them build their profile. Knowing a foreign language paid them well and also provided faster promotions. Also, few said that learning a European Language helps them for higher studies in the country where is it spoken and also is a helpful tool for people who love travelling. Among these, the other reasons were, learning for leisure, passion to learn different languages and to gain marks in the $11^{\text {th }}$ and $12^{\text {th }}$ grade examinations. 
"I identified 4 or 5 reasons to learn a language. First, professional reasons....first people learn a language either for their current job...to meet professional needs either for their promotion so that they can move to a better position inside the company itself...Some work...some study languages in order to get additional skills on their resume, they have no idea ... precise idea on why they need it or it is an investment on future...I would say.....Then some of them take French for higher studies...France is renown for its engineering schools and business schools, they are taught in English but French will be useful if they like to make friends... Also, immigration, mainly to Canada because if you want to immigrate to Canada you need to master in both French and English...”

(Director, French language institute, Chennai)

\section{Reasons for keeping up the motivation:}

There were varied reasons for keeping up the motivation to learn a language. They were 1) The teachers who keep the class lively and active and encourage the students. 2) The need to communicate and write in the language. 3) Faring well in the class 4) internal motivation 5) The excitement to learn something new every time.

"It is the way they teach. I am really liking it. I get appreciated for what I do in exam and projects."

(Student, French language institute, Chennai)

"The class must be lively. Language must be learnt by enjoying it."

(Director, French Language Institute, Chennai)

\section{Role of a professor in keeping student's motivation:}

On being asked about what the role of a professor is in keeping student's motivation, many said that using tools like videos, songs, movies, etc., by the teacher interests the students and sustains their motivation. Also, the teacher must encourage the students when they fare well and not discourage them when they make an error. Rather, they felt that, the teacher can help the students work on their weakness. The teacher can use simple sentences instead of complicated sentences and also wait till the student finishes his line to correct his/her mistakes, as reported by a few.

"My teacher put me under the spot light by giving me to do a small play which was being video recorded. This made me realise that I could do thing on the spot. I do not have to prepare anything and I know the language and that I know how to speak in the language. If he hadn't put me on that spot, I wouldn't have known. My confidence level went way up".

(Student, Russian language institute, Chennai) "Professor has to motivate the student to speak the language from the first day"

(Student, Russian language institute, Chennai) 


\section{Change of teacher:}

Six out of ten students felt that change of teacher during the middle of the course will definitely affect them as the already built rapport will be disturbed. The time taken for the new rapport to be formed will demotivate them. While the rest felt that it is fine if a new teacher takes in charge until he/she is better than or equal to, in calibre, the old teacher.

"The previous teacher would have known the strength and weakness of the students but the new teacher would not. It takes a while to gel."

(Student, French language institute, Chennai)

\section{One-to-One or Group attention:}

Most of the students preferred the teacher attending them as groups as it enables more interaction, exchange of ideas and also rectification of errors. Also, it encourages interpersonal relationship among those in the class. While, people who preferred one-to-one attention said that it is better because students who don't fare well need extra attention which is not given when the students are approached as a group.

"When approached as a group you won't feel close to the language"

(Student, French language institute, Chennai) "I get so demotivated when I am given one-to-one attention. I prefer my classmates interacting with me rather than the professor as he is definitely much knowledgeable than me."

(Student, Russian language institute, Chennai)

\section{Attrition rate of students and the solution:}

Majority of the interviewees said that personal reasons and lack of motivation are the causes for any student to drop out during the course. The other reasons cited were, unfriendly nature of the teacher, misjudging the depth and difficulty level of the language, academic reasons, health issues. Mismanagement of time and lack of proper scheduling of classes by the teachers and students' needs not being fulfilled are also said to be two of the major reasons. Many of them felt that it is better to start learning a language only after assessing the importance of the language, the difficulty of the language and passion to learn the language. Also, the professors and the peer group can motivate the student if he/she is demotivated by exposing the student to interesting aspects of the language.

"I work in Bangalore and I come to Chennai every weekend to attend the classes out of selfinterest."

(Student, French language institute, Chennai) "At the University level it is very difficult to explain. There is an interest for some language suddenly spurting up and there is an equal disinterest spurting up suddenly after sometime."

(Head of the department, University, Chennai) 


\section{Effect of previously learnt language:}

It is observed that previously learnt language affects the learning of a new language both positively and negatively. While it motivates the students who fared well in the previous language to learn the new language effectively, it acts as a mental block for those who had a bad experience learning the previous language.

"We find repeat students in our department. Those who chose Spanish initially want to do two semesters of Spanish and come back and say that they want to do two semesters of Italian. If it is a pleasant experience they definitely want to come back."

(Head of the Department, University, Chennai) "Lot of words are similar between Dutch and French and also I now know the procedure to learn a language"

(Student, French language institute, Chennai)

\section{Importance of life skills and language skills:}

Most of the interviewees said that life skills are important and they have to be integrated along with the syllabus. While it is already a part of the syllabus in private language institutes (debates, group discussions that encourage public speaking and interpersonal communication), it is difficult to imply the same in Universities as there is time constraint to focus on those. Since, University classrooms comprise of 50-65 students, activities that develop life skills are very hard to bring into action, they say. Activities like extempore, debates, dialogue exchange enable students to develop their life skills. Also, concentrating on pronunciations, accents and vocabulary is very essential for effectively learning a language, as reported by the students.

"My teacher makes sure that she gives us all a topic for the weekend and makes us come in front of the class and talk about it"

(Student, French language institute, Chennai) "Language has to be spoken more than be written. For that proper accent and vocabulary is important"

\section{Effects on creativity:}

(Student, Russian language institute, Chennai)

It is observed that learning a language has paved way to the increased creativity levels among the students. Most of them report increase in creativity as they are given constant practise on writing short stories, small essays on random topics and to express their opinion on the same. Many of them feel that they could relate to the things around them using the language.

"I write short stories for children in English. Learning a new language has enabled me to think more creatively on that grounds and made me fare better."

(Student, French language institute, Chennai) "You find students venturing into poem writing, essay competitions, who haven't done that before, after starting to learn the language. They find a means to express their creativity, which is done by improving their vocabulary and grammar"

(Head of the department, University, Chennai) 


\section{Teaching in a practical way:}

Most of the respondents feel that learning the language in a practical way is more effective than that of the theoretical way as the former is more interesting and enjoyable which adds on to the motivations of the students. Using materials like videos, music and movies, role plays are said to be effective in their own ways for learning a foreign language.

"It is a different case when it comes to Mathematics or Chemistry. A language has to be learnt in the practical way by speaking”

\section{Current materials used and the content to learn the language:}

(Student, Russian language institute, Chennai)

On being asked to comment on the current materials and its content used to learn language, everybody were satisfied with them as they are up to date. Apart from books, various materials like CDs and Maps and media are also used widely for teaching the language which acts as a motivating factor for the students. Many said that come what may, nothing replaces a good teacher.

"The new materials gives you more possibilities to learn but it cannot replace a good teacher"

(Director, French language institute, Chennai)

\section{Using smart boards and computer associated learning tools:}

Though few of the respondents up voted the presence of smart boards for teaching the language, majority of them were confident about their stand that the old school method, the books are always an effective tool than smart boards. They said that the presence of smart boards don't make a difference and does not impact their learning. Also, it was reported that using computer associated tools for learning is really helpful when the professors can't be approached and to learn new words and use them in conversations.

"I am not from that generation but as of what I have heard, smart boards do make a difference"

(Student, French language institute, Chennai)

"It might add colours to the learning process, but that does not account for a significant impact" (Student, French language institute, Chennai)

"Teachers won't be available all the time, in such case, these applications are so helpful."

(Student, French Language Institute, Chennai)

"Various mobile applications are invented nowadays which seem to helping the students with their preparation”

\section{Outputs of learning a language:}

(Head of the department, University, Chennai)

It is observed from the responses of the interviewees that language learning has significantly increased the confidence and self-esteem levels of the students. Also, they found themselves developing personally and they took pride in learning a language as it enabled them to stand out of the crowd. Learning a foreign language also creates an understanding between cultures. It has also helped them shed their fear and inhibition and face the native speakers confidently. 
"In the first year the students hide behind one another after seeing a foreigner. In the fourth semester they volunteer to go up to the foreigner and speak confidently"

(Head of the department, University, Chennai) "Learning the language helped me get into its anthropology. It was not by language but through language I could understand myself"

(Student, Russian language institute, Chennai)

"When I say I know a foreign language, the number of raised eyebrows I get from my friends and the people around boosts my confidence and self-esteem."

(Student, French language institute, Chennai)

\section{DISCUSSION:}

Motivation to learn second and foreign language can be intrinsic or extrinsic. It is usually a combination of both. Intrinsic motivation is instrumental in providing the first impetus to learn the language. In our study, it is reported that factors of instrinsic motivation are predominantly career related. But irrespective of the factors of intrinsic motivation, extrinsic motivation is relatively uniform. This supports the hypotheses that motivation can overrule aptitude and other factors (Gardner, 1972).

Extrinsic factors can be personal achievement, relationship with significant others and the methods used. The personal success in learning the language reinforces the intrinsic motivation. This builds the self confidence and thereby strengthens the determination to continue the course. This supports the linguistic self-confidence concept of Richard Clement and the selfdetermination theory.

Students develop significant relationships during the course with the teacher and peers. Any maladjustment in these interpersonal relationships has a negative impact in the motivation of the students. Further, the methods used by the teacher and the tools used for each class determines the interest and involvement of the students in learning the language.

Considering these findings, it can be recommended that teachers should give extra attention to reinforce these intrinsic motivations. Techniques to integrate motivation along with the regular classroom teaching is essential to ensure retention. Social learning that allows the development of significant relationships between teachers and peers should be encouraged. Methods and tools of language learning should be customised for classrooms.

The study was limited by a limited sample size and sample being recruited from the urban population. More studies are required to explore more participants including rural foreign language learners. 


\section{Acknowledgements:}

We would like to thank the Department of French and Foreign languages, University of Madras, Tamil Nadu, India and Alliance Française of Madras, Tamil Nadu, India for their valuable support and inputs.

\section{REFERENCES:}

Brown, R. (1973). A First Language. Cambridge: Harvard Press.

Charmaz, Kathy. "Constructing grounded theory: A practical guide through qualitative research." Sage Publications Ltd, London (2006).

Clément, R., Dörnyei, Z., \& Noels, K. A. (1994). Motivation, self-confidence, and group cohesion in the foreign language classroom. Language learning, 44, 417-417.

Dickinson, L. (1995). Autonomy and motivation a literature review. System, 23(2), 165-174.

Dulay, H., \& Burt, M. (1975). A new approach to discovering universal strategies of child second language acquisition. Georgetown University Round Table on Languages and Linguistics, 209-233.

Eccles, J. S., \& Wigfield, A. (1995). In the mind of the achiever: The structure of adolescents' academic achievement related-beliefs and self-perceptions. Personality and Social Psychology Bulletin, 21, 215-225.

Gardner, R. C., \& Lambert, W. E. (1972). Attitudes and Motivation in Second-Language Learning.

Gibson, W., \& Brown, A. (2009). Working with qualitative data. Sage.

Jafari,S. (2013). Motivated learners and their success in learning a second language.

Krashen, S. and H. Seliger (1975) "The essential contributions of formal instruction in adult second language learning." TESOL Quarterly 9: 173-183.

Pintrich, P. R., \& Schunk, D. H. (2002). Motivation in education: Theory, research, and applications. Prentice Hall.

Schumann, J. H., Crowell, S. E., Jones, N. E., Lee, N., \& Schuchert, S. A. (2014). The neurobiology of learning: Perspectives from second language acquisition. Rout ledge.

How to cite this article: B Poornima, H Jayaraman, A Kumar (2016), Factors Influencing Second Language Learning Among Urban European Language Learners: A Qualitative Study, International Journal of Indian Psychology, Volume 3, Issue 3, No. 7, DIP: 18.01.120/20160303, ISBN: 978-1-365-12175-3 